\title{
A CONTRIBUTION TO THE ETIOLOGY OF BERI-BERI.
}

\author{
By S. KAJIURA, Imperial Japanese Navy \\ anp O. ROSENHEIM, Ph.D. \\ (From the Physiological Laboratory, King's College, London.) \\ Plate VI.
}

No hypothesis hitherto advanced with regard to the origin of BeriBeri, has up till now found sufficient experimental confirmation to warrant its general acceptance. This applies especially to the conception of the disease as due to the presence of bacteria or parasites in the blood, further to the infection theory as well as to the miasmatic theory ${ }^{1}$.

One fact, however, stands out clearly and is now generally admitted by modern investigators, namely that there is some connection between Beri-Beri and rice. In all those eastern countries in which the disease is endemic, rice forms the staple food and it may be safely said that, in Japan at least, every sufferer from Beri-Beri is a rice eater and that conversely European residents who eat little or no rice do not get Beri-Beri.

In considering this subject the treatment which the rice has undergone previous to its consumption as food, plays an important rôle. The rice consumed in Japan is mainly so-called "white rice," i.e. rice freed from pericarp and husks, and finally "polished." As we were mainly concerned with the investigation of this kind of rice, the other qualities ("red" rice, "cured" rice, etc.) may be left out of consideration here, although their importance with regard to the origin of Beri-Beri in other eastern countries is obvious.

1 No attempt has been made to deal in this short communication with the extensive literature of the subject. Very full references to it will be found in W. L. Braddon's monograph, The Cause and Prevention of Beri-Beri, London, 1907. See also: H. Dürck, Unters. über die path. Anat. d. Beri-Beri, Jena, 1908.

Journ. of Hyg. $x$ 
On the basis of the assumed relationship of a rice diet to Beri-Beri, two principal hypotheses have been brought forward to explain the nature of this relationship. The one hypothesis assumes that a rice diet is physiologically incorrect, owing to the large excess of carbohydrates over nitrogenous and fatty food stuffs', whilst according to the other hypothesis Beri-Beri is caused by an unknown poison (alkaloid, ptomaine, toxin) conveyed by and generated in rice by either a mould, microbe, enzyme or some other agency.

Both of these hypotheses have received a certain amount of experimental confirmation, the results of which, however, may be equally well explained by either of the two hypotheses. The main weakness of the "poison" hypothesis consists in the fact that all attempts made to isolate what should be a most intense poison have so far been unsuccessful, whilst the astonishingly beneficial results which have been achieved in Japan by merely replacing a certain percentage of rice by nitrogenous food stuffs ${ }^{2}$, speak strongly in favour of the first mentioned hypothesis, namely, that lack of nutritive material or an unphysiological diet is the cause of Beri-Beri.

In the course of these dietetic changes, introduced first on a large scale in the Japanese navy by Takaki, it was found that the men showed a disinclination to take meat and bread. It was therefore proposed to use barley and rice in equal quantities instead of rice alone. Since the introduction of this change in the navy, not only has BeriBeri been wholly exterminated but also other general diseases have greatly decreased (Takaki, loc. cit.).

The fact that the partial replacement of rice by another cereal like barley is able to prevent the onset of the disease is especially interesting, if we consider the chemical composition of these cereals. It is commonly assumed that the composition of the various cereals only varies witbin narrow limits and the agreement in the nitrogen percentage of barley and rice, in any case, is very close. According to the analyses given in the report of the Hygienic Laboratory of the Japanese Department of Home Affairs (1897) the average nitrogen percentage of Japanese rice is $1.37 \%$, whilst that of Japanese barley is $1.82 \%$ (calculated for

1 It must be mentioned in this connection that, besides containing a relatively small percentage of nitrogen, "white rice" is also very poor in calcium and phosphorus. The lack of these two latter important constituents of a physiological diet, has also been adduced in explanation of the origin of Beri-Beri (see later).

2 See also Baron Takaki's lectures, The Lancet, Vol. cLxx. 1906, p. 1369. Before the new diet was introduced the number of Beri-Beri cases was 325 per 1000 with 41 deaths annually. With the change of diet the number fell to 127, 6 and 0.4 and finally nil. 
dried material). König ${ }^{1}$ gives $1.52 \% \mathrm{~N}$ for Japanese rice and $1.55 \% \mathrm{~N}$ for barley (from Asia).

The beneficial results due to barley, if connected with the nitrogen factor at all, would seem therefore not to be dependent on the amount of nitrogen, but on the nature of the nitrogenous substances.

Until recently nothing was known about the nature of the proteins contained in rice. An investigation carried out by us $^{2}$, furnished the remarkable result that the alcohol-soluble proteins (gliadins ${ }^{3}$ ) present in all the known cereals are absent in rice. This fact appears to be of significance in several directions. It explains the impossibility of using rice as a material for making bread. The formation of gluten, the characteristic protein-mixture which enables flour to be converted into dough, is only possible in the presence of a gliadin. The absence of this protein may further conceivably have a bearing on the dietetic value of rice. Gliadins are characterised by the high percentage of glutaminic acid, proline and ammonia amongst their cleavage products. As according to modern views the proteins are broken down completely in the alimentary canal into their cleavage products (mainly amino-acids), before being resynthesised in the body, and as the absence of any one of these amino-acids seems to be intimately connected with the food value of different proteins, it appears justifiable to assume that the absence in rice of such a typical protein as the gliadin, may furnish an explanation of the non-efficiency of the rice diet.

This question can be attacked experimentally by means of feeding experiments on animals. Eykman ${ }^{4}$, and later Grijns ${ }^{5}$, found that an exclusive rice diet produces in fowls a form of polyneuritis, the symptoms, the course and the morbid anatomy of which agree closely with human Beri-Beri. As in the latter, the disease is prevented in fowls if barley, oats or rye are given ${ }^{6}$. These experiments were carried

1 T. König, Chem. Zusamm. d. menschl. Nahr. u. Genussm. Vol. I. 1903.

2 The Proteins of Rice, Proc. Physiol. Soc. xxxvi. 1908, p. liv. A full communication of this research will appear shortly.

3 The name "gliadin" as a general name for the alcohol-soluble proteins was proposed by O. Rosenheim (Science Progress, April, 1908, No. 8) and seems preferable to the term "prolamine" proposed by T. B. Osborne (Science, N. S. xxvirr. 1908, p. 417) as the resemblance of this name to "protamine" might easily give rise to mistakes.

4 Virch. Arch. Vol. cxuvir. 1897, p. 523, Arch. f. Hygiene, Vol. Lvirr. 1906, p. 150. We were unable to obtain Eykman's first publication, Geneesk. Tydschr. v. Ned. Indie, 1890 , in the original.

5 Geneesk. Tydschr. v. Ned. Indie, 1901, quoted from Eykman. See also: Arch. $f$. Hygiene, Vol. Lxir. 1907, p. 128.

"It is also prevented if " unpeeled" or "cured" rice is given, but for reasons stated above these factors need not be considered here. 
out in Java and exception has been taken to the results, because they were obtained in a possibly "infected" locality".

In order to investigate the question raised by the absence of an alcohol-soluble protein in rice, we carried out feeding experiments on fowls by adding the alcohol-soluble protein of barley (hordein) to their rice diet. In view of the statements that Beri-Beri may be due to the lack of calcium (and a subsequent oxalic acid intoxication ${ }^{2}$ ) we also made some experiments in which large quantities of calcium carbonate were added to the food. With regard to the lack of phosphorus it has already been shown by Eykman (loc. cit.) that the addition of the organic phosphorus compound contained in rice husks (phytin) is unable to prevent the disease ${ }^{3}$. It seemed interesting to examine the effect of an inorganic phosphorus compound and we chose calcium phosphate, thus introducing large quantities of calcium and phosphorus at the same time. The effect of these salts was investigated when added to an exclusive rice diet as well as to the rice and hordein diet. Although our experiments are not as numerous as we should wish (owing to the appearance of an infective disease amongst our stock of fowls and also for other reasons) the negative character of the results warrants a short communication.

Description of experiments: Twelve apparently healthy fowls of different breed were used, the birds taken for the corresponding groups of experiments being matched as far as possible in age, weight and breed. They were kept in pairs in separate large wire coops, the floor of which was covered with gravel frequently renewed. The coops were cleaned and disinfected regularly. The birds were weighed at the beginning and at frequent intervals during the course of the experiments. They were allowed exercise daily and were fed, as a rule, twice daily. The fowls fed with barley were allowed to take their food freely. Those fed with rice had to be fed by hand, as they

1 See, however, Eykman (loc. cit.).

2 G. Maurer, Münch. med. Wochenschr. Vol. LIv. I. 1907, p. 731. Also Geneesk. Tydschr. v. Ned. Indie, 1901, quoted from A. Treutlein, Verhandl. d. phys. med. Ges. Wilrzburg, Vol. xxxvin. 1906, p. 323 ; see also C. Eykman, Münch. med. Wochenschr. Vol. LIv. I. 1907, p. 127.

3 H. Schaumann (Verhandl. d. d. tropenmed. Ges. 1908) ascribes the symptoms of Beri-Beri to the lack of nucleo-phosphoric acid in food. Since this paper has gone to the press an important preliminary communication on this subject has been made by $H$. Fraser and A. T. Stanton (Studies from the Inst. f. Med. Research, Fed. Malay States, Kuala Lumpur). These authors find that the addition to a "white rice" diet of the alcoholsoluble substances (lipoids) extracted from parboiled (cured) rice prevented the development of polyneuritis in fowls and that the estimation of the total phosphorus present in a given rice may be used as an indicator of the Beri-Beri producing power of rice. 
soon began to refuse rice food ${ }^{1}$. For this purpose the daily portion was powdered and made into pills (the size of a pea) after the addition of a small quantity of water. The animals swallowed these pills easily, when they were introduced a few at a time into their beaks, followed by small quantities of water. All the birds were allowed to take water freely. The rice used was obtained directly from Japan and of the quality usually consumed in that country. On analysis it was found to contain 13.00\% Water, and in the dried material: Nitrogen, 1.24 \% , Phosphorus, $0.13 \%$, Calcium, 0.03\%.

The hordein used in these experiments was prepared from $10 \mathrm{kgs}$. of barley by extraction with $70 \%$ alcohol. The extracts were concentrated by distillation in vacuo and the precipitated hordein purified in the usual way', finally washed with alcohol and ether, and dried in vacuo over concentrated sulphuric acid. The amount given with the rice corresponded roughly to that contained in an equal amount of barley. In one set of experiments gluten (i.e. a mixture of gliadin and glutenin) from wheat was added to the rice diet.

The following foods were given, two birds being fed on them in each case :

(1) Rice alone.

(2) Rice + Hordein (Barley).

(3) Rice + Gluten (Wheat).

(4) Rice + Calcium carbonate. ditto + Calcium phosphate.

(5) Rice + Hordein + Calcium carbonate. ditto ditto + Calcium phosphate.

(6) Barley alone.

Further details are given in the following table.

It will be seen that all the birds fed on rice or on rice and hordein (or gluten) died within the relatively short time of 16-24 days. Death was due in all cases to typical polyneuritis. There was at first general weakness and later evident paralysis, which became usually very marked on the 10th-12th day. The legs seemed affected first, the wings later. The walk was typically unsteady, the birds were unable to sit on the roost and their wings drooped. There was marked loss of sensation

1 They showed, however, great avidity for barley which they tried to snatch from the other coops, when allowed near them.

2 T. B. Osborne, Journ. Amer. Chem. Soc. Vol. xvir. 1895, p. 539 ; see also V. Griessmayer, Die Proteide der Getreidearten, Heidelberg, 1897. 
to stimuli, dyspnoea, emaciation, and finally death followed general paralysis.

Identical results supervened when calcium carbonate or calcium phosphate was added to the rice diet or to the rice + hordein diet.

\begin{tabular}{|c|c|c|c|c|c|c|}
\hline \multirow[b]{2}{*}{ No. } & \multirow[b]{2}{*}{ Breed } & \multicolumn{2}{|c|}{$\begin{array}{c}\text { Weight } \\
\text { in grammes }\end{array}$} & \multirow[b]{2}{*}{ Kind of food } & \multirow{2}{*}{ Quantity of food } & 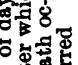 \\
\hline & & Before & After & & & \\
\hline 1 & Buff Orpington & 1840 & 1795 & Rice & 100 grs. reduced to 50 grs. & 16 \\
\hline 2 & White Leghorn & 2005 & 1720 & ", & after the 6th day & 17 \\
\hline 3 & Buff Orpington & 1930 & 1750 & Rice + Hordein & 50grs.Rice, $2 \cdot 5$ grs.Hordein & 15 \\
\hline 4 & White Leghorn & 1840 & 1795 & , & ," & 22 \\
\hline 5 & Plymouth Rock & 1865 & 1405 & Rice + Gluten & 50 grs.Rice, $2 \cdot 5$ grs. Gluten & 22 \\
\hline 6 & $"$ & 1708 & 1508 & , & , & 17 \\
\hline 7 & Black Minorca & 1555 & 1302 & $\mathrm{Rice}+\mathrm{CaCO}_{3}$ & 40 grs. Rice, 4 grs. $\mathrm{CaCO}_{3}$ & 14 \\
\hline 8 & Plymouth Rock & 1525 & 一 & Rice $+\mathrm{Ca}_{3}\left(\mathrm{PO}_{4}\right)_{2}$ & 40grs.Rice,4grs.Ca $\left(\mathrm{PO}_{4}\right)_{2}$ & 24 \\
\hline 9 & Black Minorca & 1945 & 1531 & $\begin{array}{l}\text { Rice }+ \text { Hordein } \\
+\mathrm{CaCO}_{3}\end{array}$ & $\begin{array}{l}40 \text { grs. Rice, } 4 \text { grs. } \mathrm{CaCO}_{3} \text {, } \\
2 \text { grs. Hordein }\end{array}$ & 19 \\
\hline 10 & Plymouth Rock & 1895 & 1745 & $\begin{array}{l}\text { Rice + Hordein } \\
+\mathrm{Ca}_{3}\left(\mathrm{PO}_{4}\right)_{2}\end{array}$ & $\begin{array}{l}40 \text { grs.Rice, } 4 \text { grs.Ca } a_{3}\left(\mathrm{PO}_{4}\right)_{2}, \\
2 \text { grs. Hordein }\end{array}$ & 23 \\
\hline 11 & Buff Orpington & 2247 & 1498 & Barley & Freely & 01 \\
\hline 12 & $"$ & 2145 & 1777 & $"$ & " & 42 \\
\hline
\end{tabular}

In all cases the sciatic and brachial nerves were examined by Marchi's method. They showed distinet and in some cases very marked degeneration (see Plate VI), thus confirming the clinical symptoms and the microscopic post mortem changes.

The two control birds fed on barley did not show any of these symptoms. They lived much longer than the other birds, but died unfortunately from an infectious bacterial disease (probably chicken cholera ${ }^{1}$ ), which also attacked and killed rapidly the fowls intended for further investigations. In one of the control animals(No. 11) a number of degenerated fibres were found in the sciatic nerve, although the animal had not shown any paralytic symptoms. A similar observation has also been made by Eykman (loc. cit.).

These experiments prove therefore that Beri-Beri, or a disease very similar to it, can be produced in fowls simply by a diet of peeled rice, independently of influences of climate or locality. This fact seems to

1 Prof. Hewlett kindly examined one of these birds in the Bacteriol. Laboratory, King's College, London. A micro-organism was isolated, which belonged to the group of chicken cholera organisms. We are greatly indebted to Prof. Hewlett for his help in this matter. 


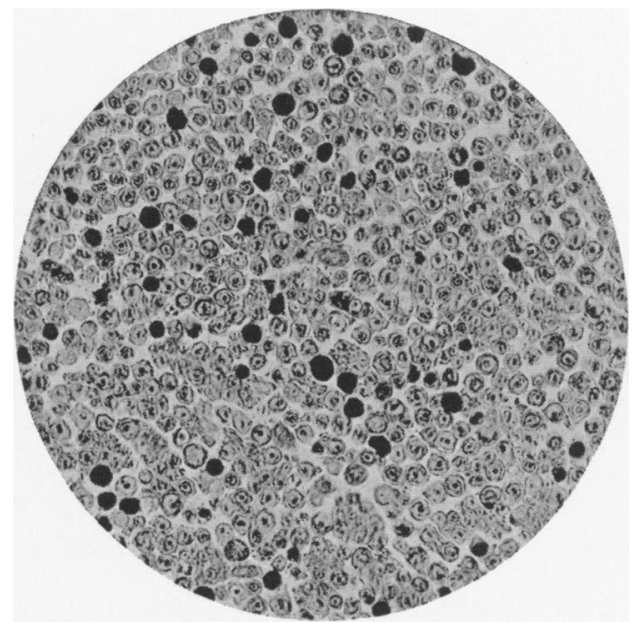

Fig. 1. Photograph showing degeneration of sciatic nerve after rice + hordein diet. Marchi's method. Transverse section.

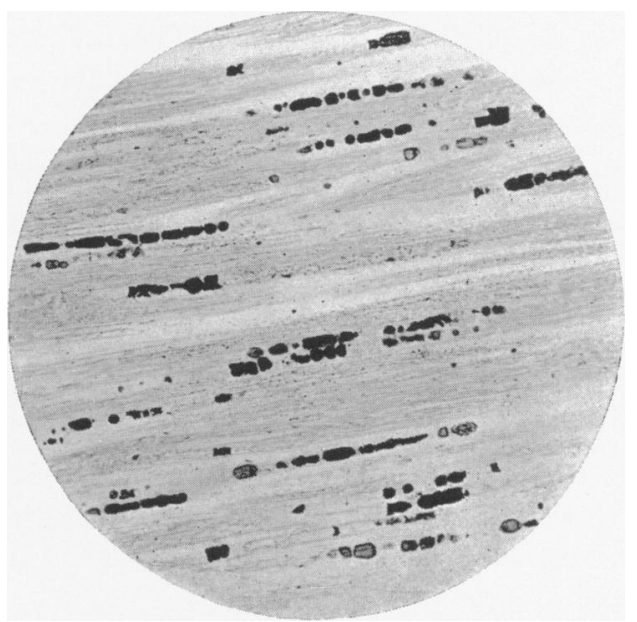

Fig. 2. Photograph showing degeneration of sciatic nerve after rice + hordein diet. Marchi's method. Longitudinal section. 
be of importance for the physiology and hygiene of nutrition, demonstrating the inefficiency of an exclusive rice diet to sustain life.

It would further seem that the alcohol-soluble protein of barley, at any rate in the quantities used, is unable to prevent the disease and that the beneficial action of barley, when added to a rice diet, is due to another constituent of this cereal.

The addition to a rice diet of large quantities of calcium and of phosphorus (as calcium carbonate and calcium phosphate) seems also unable to prevent the disease.

The expenses of this investigation have been in part defrayed out of a grant from the Government Grant Committee of the Royal Society. 